\title{
Industry aspects of farm access to high value- added supply chains
}

\author{
Aleksandr Kudryavtsev * and Yuliya Karmyshova \\ Penza State Technological University, Department of Economics and management, 440039, Penza, \\ Russia
}

\begin{abstract}
This paper examines the factors characterizing the access of farms to the supply chains of agricultural products with high added value. Indicators of statistical reporting on farm activity grouped by type of products are analyzed, on the basis of which the influence of production size on opportunities selling products at a higher price is assessed. It is concluded that for various sectors of agriculture the level of product sale prices' dispersion by individual farmers differs, which characterizes differences and opportunities of farmers to increase own share in the added value creation chain. Identified types of agricultural products, producers of which must increase production volumes to gain access to more profitable trade channels of products, as well as types of products where significant production volume is not a prerequisite for higher sales prices. These conclusions can be taken into account in assessing the feasibility of establishing marketing or processing consumer cooperatives of farmers.
\end{abstract}

\section{Introduction}

Many scientific studies have been devoted to the study of various aspects of food supply chains. The issues of coordination of such chains participants' interests $[1,2,3]$, factors of supply chains stability [4,5], interaction within the framework of integrated formations $[6,7]$. Food supply chains are seen as complex systems of interaction, elements of which are different economic agents providing some input to the formation and promotion of the product to the end consumer. Each participant in the supply chain acts on its own interests and objectives, but collectively they form essentially a "hybrid institution" - a single organizational structure, ensuring the creation of the product and bringing it to the consumer [8]. Polar variants of supply chain organization can be considered two types of structures, which in pure form practically do not occur. The first type is characterized by the fact that each stage of the chain is localized within a separate firm, the second - that all stages are implemented within a single vertically integrated firm. Certain agricultural markets are characterized by a variety of intermediate supply chain management options involving vertically and horizontally integrated firms, as well as economic agents that ensure that only one step of value creation is implemented. As a result, conditions arise for asymmetrical distribution of value added among chain participants [9].

\footnotetext{
*Corresponding author: kudryavcev_a@inbox.ru
} 
The nature of interaction and the number of participants in the product supply chain are largely determined by the nature of the products offered to the end user. Thus, deepening the reworking process of raw agricultural materials or products increases the added value, but also increases the number of participants in the supply chain and complicates the interaction processes between them, as well as external government regulation. The end consumer determines the level of interdependence between the participants in the supply chain by placing certain requirements on the quality of products. From this point of view, the supply chain can be seen as a process of mutual creation of added value based on the requirements of the end consumer [2].

Producers of agricultural products in competitive conditions face the need to choose whether to focus on reducing production costs in order to offer the consumer a minimum possible prices for standard products or choose sales channels with a high level of added value, to develop market segments with higher solvency of buyers wishing to purchase expensive but higher quality, ecological and diverse products. In the context of highintensity production of uniform quality products, interaction between producers and other supply chain participants may be short-term, non-recurrent and to be limited only directly to the sale transaction. If products are differentiated (for example, in quality, place and characteristics of production), then manufacturers, processors and sellers are more inclined to organize interactions on the long-term basis, including to be united in cooperative formations [10].

Countrymen often prefer consuming products of local origin due to the close territorial proximity to producers, desiring to support the development of their community. This creates conditions for the organization of short product supply chains. Short supply chains, which imply that rural consumers are focused on buying products from local producers, affect the sustainability of social sphere development [11]. The supply chain of products can be seen as an alternative based on its opposition to traditional, primary supply channels. The main characteristics of alternative food supply chains can be identified as the following: territorial proximity of producers and consumers; suppliers are small farms often committed to organic production principles; presence of a network of farmers-produced sales points directly to consumers (farmers markets and weekend fairs, online sales with delivery); the producers orientation to the sustainability of the relevant rural area development [12]. Alternative food supply chains are therefore generally short, minimizing middlemen's share of added value while improving profitability of direct producers' activity and the availability of goods to consumers. In addition, manufacturers get the opportunity of close interaction with the end consumer, which creates conditions for improving products and increasing customer loyalty. Participants of alternative food supply chains define as a priority not to maximize enterprise productivity and intensify production processes, but rather the quality of products, conventionality of technologies and organicity of products [13]. Farmers' income and value added within local supply chains are more sustainable because pricing is based on cost, whereas in global chains prices depend on conditions in world markets. But it should be noted that cost pricing does not guarantee high rates of economic efficiency to the farmer, as it can be accompanied by a low load of production capacities [4].

It cannot be stated unequivocally that only the participation of farmers in short value added chains ensures that they increase their share of value added. Just as the same can't be argued for long, global food supply chains. The following factors contribute to the participation of farmers in high value-added chains: access to information on market prices and market forecasts; use of contract farming; product quality increase and its certification; intensification of production technologies [14]. The efficiency of the product supply chain depends to a large extent on uncertainties, the probabilistic value of organizational and environmental variables [15]. It can be argued that the identified factors are depending on 
the industry characteristics of management, such as the level of capital concentration, the duration of the production cycle, terms and conditions of agricultural raw materials and finished products storage, etc. The purpose of this study is to assess the influence of certain factors on the possibilities of farms operating in various sectors of agriculture to sell products at higher prices.

\section{Materials and Methods}

This work is based on the study of scientific publications on the subject of research. Statistical statements of farms (Farming holding form 1) of Penza region for the year of 2018 were used as a source for the analysis of the actual data. Penza region is a subject of the Russian Federation, in the structure of gross regional product of which the share of agriculture accounts for $13 \%$. A total of 511 farms were analyzed.

As part of the study, we assumed that the access of a particular farm to a higher value added distribution channel is to some extent characterized by product sale price level. That is, a farm that sells products at a higher price provides a higher share in the value added structure for itself. Accordingly, the comparison of farms by price level makes it possible to assess the relative availability of such channels for individual activities. A variation factor was calculated to estimate the level of price range. The dependence of farm opportunities to provide a higher price level on individual factors was estimated based on Spearmen's rankorder correlation coefficients. To this end, farms were ranked by the sale price of certain product types, as well as by the assumed factor values: sown area, yield, income from sales, livestock inventory quantity.

\section{Results and Discussion}

As part of the analysis, farms were grouped by type of products sold and were also ranked by level of income received for the period. For producers of wheat, sunflower, sugar beet, milk the farms which received annual income of at least 1 million rubles were selected; for producers of potatoes, meat of cattle and pigs - at least 0.3 million rubles. In table 1 , the crop analysis results are presented.

Table 1. Results of sale price level analysis of farm crop products

\begin{tabular}{|l|c|c|c|c|}
\hline \multirow{2}{*}{\multicolumn{1}{|c|}{ Indicator }} & \multicolumn{4}{|c|}{ Product type / number of farms analyzed } \\
\cline { 2 - 5 } & $\begin{array}{c}\text { Wheat / 180 } \\
\mathbf{( 2 5 )}\end{array}$ & $\begin{array}{c}\text { Sunflower / 138 } \\
\mathbf{( 2 5 )}\end{array}$ & Potatoes / 19 & $\begin{array}{c}\text { Sugar Beet / } \\
\mathbf{2 8}\end{array}$ \\
\hline $\begin{array}{l}\text { Price variation } \\
\text { coefficient, \% }\end{array}$ & 24.14 & 21.57 & 42.71 & 17.36 \\
\hline $\begin{array}{l}\text { Rank coefficient of } \\
\text { price and yield } \\
\text { correlation }\end{array}$ & $\begin{array}{c}0.16 \\
(0.21)\end{array}$ & $\begin{array}{c}0.07 \\
(0.02)\end{array}$ & 0.28 & 0.09 \\
\hline $\begin{array}{l}\text { Rank coefficient of } \\
\text { price and } \\
\text { harvested acreage } \\
\text { correlation }\end{array}$ & $\begin{array}{c}-0.05 \\
(-0.34)\end{array}$ & $\begin{array}{c}-0.09 \\
(-0.17)\end{array}$ & 0.37 & 0.10 \\
\hline $\begin{array}{l}\text { Rank coefficient of } \\
\text { price and sales income } \\
\text { correlation }\end{array}$ & $\begin{array}{c}0.21 \\
(-0.15)\end{array}$ & $\begin{array}{c}0.08 \\
(0.24)\end{array}$ & 0.81 & 0.29 \\
\hline
\end{tabular}

From table 1, we can see that the prices of potatoes for the research farms summation are highly heterogeneous, for other types of products the price differences can be described as 
moderate, but significant enough. Accordingly, potato producers are more restricted in access to better sale channels. At the same time, the dependence of the farmer's ability to provide higher sales prices on the scale of the farm's activity is also observed for potatoes. In order to reflect the scale of farm activity in the calculation of correlation coefficients the indicator of the harvested acreage and the received income from the sale of the corresponding products were chosen. The yield indicator is chosen for comparison as it reflects to some extent the farmer's level of production intensification, its efficiency. It can be concluded that potato-producing farmers should seek to increase production in order to gain access to higher value-added chains. It is conceivable that a similar effect will be achieved by co-operating several small producers.

Due to the fact that the Spearmen's coefficient can produce inaccurate results for a large number of values, for wheat and sunflower this figure was also determined from a sample of 25 farmers with a maximum level of income. In this sample for wheat, there is little feedback between the farmer's ability to get a higher sales price and the sowing area. It can be assumed that with the increase in the acreage above a certain limit, farmers are forced to sell more substantial amounts of grain at lower prices. Other dependencies have not been identified. Let us consider similar indicators for livestock production.

Table 2. Results of sale price level analysis of farm livestock products

\begin{tabular}{|l|c|c|c|}
\hline \multirow{2}{*}{\multicolumn{1}{|c|}{ Indicator }} & \multicolumn{3}{|c|}{ Product type / number of farms analyzed } \\
\cline { 2 - 4 } & Cattle meat / 26 & Pork / 7 & $\begin{array}{c}\text { Milk / 78 } \\
\text { (25) }\end{array}$ \\
\hline $\begin{array}{l}\text { Price variation } \\
\text { coefficient, \% }\end{array}$ & 39.77 & 42.87 & 24.29 \\
\hline $\begin{array}{l}\text { Rank coefficient of } \\
\text { price and livestock } \\
\text { quantity correlation }\end{array}$ & -0.21 & 0.41 & $0.17(-0.15)$ \\
\hline $\begin{array}{l}\text { Rank coefficient of } \\
\text { price and sales income } \\
\text { correlation }\end{array}$ & -0.23 & 0.23 & $0.49(0.26)$ \\
\hline
\end{tabular}

In this case, livestock and sales income are chosen as indicators characterizing the scale of farm activity. Cattle and pig meat prices had a high heterogeneity in the population of farms under consideration. At the same time, for pork producers, the increase in the number of livestock has a positive impact on the ability to provide sales at higher prices. Correlation coefficients for milk production were calculated both across the aggregate and for the 25 largest farms by income. In the first case, there is a moderate dependence of access to higher prices on the scale of activity. When considering the largest farms, there is no such dependence. It can be assumed that the increase in milk production volume allows to develop more profitable marketing channels for beginners with small production, then this influence evens.

Despite the assumptions made and the small number of farms analyzed by individual activities, the results can be used to further study sector features of development by farmers of chains with a higher level of value added.

\section{Conclusions}

The analysis showed that the range of products sales prices by individual farms can be quite substantial, which suggests significantly different possibilities of producers to ensure that their own share of the value chain is raised. At the same time, for different industries and 
activities, the impact of the production volume factor on access to more profitable sales channels is different. Increasing the scope of activities can lead to a positive effect in terms of increasing sales prices, primarily for activities such as potato and milk production. And in some cases, the effect of scale in terms of price can be negative. But it is the small amount of production that farmers are often seeing as a factor limiting their access to high value-added sales chains and as an incentive to cooperation. The results of the analysis do not conflict with this statement. In some cases, even small farms can provide for themselves an increase in the value chain without participating in the cooperative's activities. In other cases (production of potatoes, milk) the size of the farm is more important. Consequently, approaches to organizing cooperatives in different sectors of agriculture should vary. For example, potato and milk producers can benefit by accumulating larger quantities of products and storing them within the cooperative. Producers of cereals, sugar beet, beef and pork can benefit from cooperation not through the formation of larger batches but through deeper processing, meaning participating in the activities of processing cooperatives.

\section{Acknowledgements}

The reported study was funded by RFBR, project number 20-010-00987

\section{References}

1. A.E. Alemu, M. Maertens, J. Deckers et al. Agric Econ, 4 (9) (2016). https://doi.org/10.1186/s40100-016-0053-x

2. Y. Handayati, T.M. Simatupang \& T. Perdana, Logist. Res., 8 (5) (2015). https://doi.org/10.1007/s12159-015-0125-4

3. H.R. Lemma, Singh \& N. Kaur, SpringerPlus 4498 (2015). https://doi.org/10.1186/s40064-015-1287-x

4. F. Galli, F. Bartolini, G. Brunori et al. Agric Econ, 3 (21) (2015). https://doi.org/10.1186/s40100-015-0039-0

5. B. Pancino, E. Blasi, A. Rappoldt et al. Agric Econ, 7 (13) (2019). https://doi.org/10.1186/s40100-019-0133-9

6. F. Carillo, F. Caracciolo \& L. Cembalo, Agric Econ, 5 (19) (2017). https://doi.org/10.1186/s40100-017-0088-7

7. S. Scaramuzzi, G. Belletti \& P. Biagioni, Agric Econ, 8 (5) (2020). https://doi.org/10.1186/s40100-019-0150-8

8. A. Carbone, Agric Econ, 5 (3) (2017). https://doi.org/10.1186/s40100-017-0071-3

9. B. Velázquez, B. Buffaria, Agric Econ, 5 (16) (2017). https://doi.org/10.1186/s40100017-0084-y

10. N.J. Lees, P. Nuthall, Agric Econ, 3 (4) (2015). https://doi.org/10.1186/s40100-0140024-Z

11. A. Gaviglio, M. Bertocchi, M.E. Marescotti et al. Agric Econ, 4 (15) (2016). https://doi.org/10.1186/s40100-016-0059-4

12. E. Blasi, C. Cicatiello, B. Pancino et al. Agric Econ, 3 (3) (2015). https://doi.org/10.1186/s40100-014-0023-0

13. L. Mastronardi, D. Marino, V. Giaccio et al. Agric Econ, 7 (21) (2019). https://doi.org/10.1186/s40100-019-0142-8

14. E. Ngenoh, B.K. Kurgat, H.K. Bett et al. Agric Econ, 7 (21) (2019). https://doi.org/10.1186/s40100-019-0122-z

15. T. Linn, B. Maenhout, Agric Econ, 7 (11) (2019). https://doi.org/10.1186/s40100-0190128-6 